\title{
The Histological Differences of the Ureter in Japanese Quail (Coturnix japonica) Compared With Some Other Domestic Avian Species
}

\author{
Diferencias Histológicas del Uréter en Codornices Japonesas (Coturnix japonica) \\ en Comparación con Algunas Otras Especies Avícolas Domésticas
}

Arash Oliaii \& Behzad Mobini

OLIAII, A. \& MOBINI, B. The histological differences of the ureter in japanese quail (Coturnix japonica) compared with some other domestic avian species. Int. J. Morphol., 35(1):193-198, 2017.

SUMMARY: The aim of this investigation was to determine the histological differences of anatomical regions of the ureter in Japanese quail compared with some other domestic avian species such as pigeon, European starling and fowl. Tissue samples from proximal, middle and distal regions of each ureter were obtained and stained with $\mathrm{H} \& \mathrm{E}$, Alcian blue (pH 2.5), Periodic acid-Schiff, Masson's trichrome, Verhoeff's, and Gomori's method for reticulum. The histology and histochemistry of the ureter showed considerable differences among various anatomical regions of the ureter. No significant sex-based differences were found. The primary branches of ureter were composed of tunica mucosa, submucosa, muscularis and serosa, whereas the wall of smaller branches of ureter only consisted of epithelium and connective tissue fibers. The intraepithelial glands were not found in some region of ureter. The mucosal folds and microvilli were more identified in the proximal region than those of the other regions of the organ. The simple columnar epithelium of proximal region was changed to pseudostratified columnar in other regions of the ureter. In all different regions of ureter, lymphatic tissues were not observed in the lamina propria. The thickness of the tunica muscularis increased from the proximal to the distal region of the ureter. Unusual findings of the ureter in Japanese quail were the presence of reticular, elastic and collagenous fibers in all the connective tissues of organ, isometric longitudinal folds and muscularis mucosa.

KEY WORDS: Histology; Japanese quail; Region; Sex; Ureter.

\section{INTRODUCTION}

The avian urinary system has many functional and structural differences when compared to mammalian counterparts (Goldstein \& Skadhauge, 2000; Mobini \& Abdollahi, 2016). Birds have no urinary bladder and renal pelvis (Aughey \& Frye, 2001; Lierz, 2003; Bacha \& Bacha, 2012). The avian urinary system is consisted of paired kidneys and muscular ureters (Bacha \& Bacha). The avian renal system is quite unique among vertebrate kidneys (Echols, 2006). One of the most unique features of avian kidneys is the presence of two types of nephrons, reptilian (or cortical type) and mammalian (or medullary) types (Abdul-Gahaffor et al., 2012; Bacha \& Bacha; Dhyaa et al., 2014; Mobini \& Abdollahi). In birds, only about 10 to $30 \%$ of the nephrons are of the mammalian type (Nabipour et al., 2009; Abdul-Gahaffor et al.; Mobini \& Abdollahi). Since birds have primarily reptilian type nephrons, which produce isosmotic urine, urine concentration is limited. In most avian, the kidney is composed of three divisions: cranial, middle and caudal. Within each division are numerous functional lobules, each draining through their medullary cones into the secondary branch of the ureter. All renal lobules drain into the same secondary branch of the ureter, which then joins a primary ureteral branch (Lierz; Echols). Different renal anatomy lead to different renal diseases in birds compared to mammals (Lierz).

The Japanese quail (Coturnix japonica), is a small size bird in the pheasant family Phasianidae with big economical profits. In recent years this species has been reared intensively in Iran and is used annually for egg and meat production. Regarding the progressive interest in this field among Iranians, providing knowledge of the histology of this species could be quite valuable. This study contributes to the knowledge of the biology of this economically important bird (Mobini, 2014). 
For elucidation of the histology of the ureter, investigations have been carried out in different adult avian species, such as such as European starling (Williams \& Nicholson, 1983), duck (Mirabella et al., 1998), and pigeon (Abdul-Gahaffor et al.). However, there are no reports on the gender effects on the histology and histochemistry of the ureter in the Japanese quail. Also, research on quail in Iran has started very recently, which makes this study even more important as it is intended to be a preliminary reference for future studies. This study was aimed at investigating detailed histological features of the ureter in Japanese quail (Coturnix japonica) to reveal potential gender differences, and to compare the findings with those made in other bird species, as a contribution to the growing number of investigations of the biology of this bird.

\section{MATERIAL AND METHOD}

Twenty male and 20 female adult, clinically healthy Japanese quail (Coturnix coturnix) were used to determine the histological and histochemical structures of the ureter. All birds were collected from a local market of birds in Shahrekord city. The birds were euthanized by excess ether inhalation. Tissue samples from proximal, middle and distal regions of each ureter were fixed in $10 \%$ Bouin's solution for 24 hours and processed routinely for paraffin embedment. Transverse serial sections $(5 \mu \mathrm{m})$ were stained with $\mathrm{H} \& \mathrm{E}$ for general histological observation and a variety of techniques for types of fibers in the connective tissues: 1) Verhoeff's for elastic fibers, 2) Masson's trichrome for collagen fibers, 3) Gomori's method for reticulum (Luna, 1968).

To investigate the chemical character $(\mathrm{pH})$ of the secretion material, Alcian blue (AB) ( $\mathrm{pH} 2.5)$ was used for determining acidic mucosubstances and Periodic acid-Schiff (PAS) reaction was employed to determine neutral mucosubstances (Kiernan, 2015). Histological studies on stained sections were carried out by light microscopy.

\section{RESULTS}

No evident difference between the female and male Japanese quail was observed in the histology and histochemistry of the ureter. The primary branches of the ureter are composed of tunica mucosa, submucosa, muscularis, and serosa in both sexes (Fig. 1A). The smaller branches of the ureter (secondary and tertiary) comprised only epithelium and connective tissue fibers (Fig. 2C). The tunica mucosa of the proximal region of the ureter was mainly lined with simple columnar epithelium (Fig. 1B). However, in the middle and distal regions, the epithelium varied from simple columnar to pseudostratified columnar. The apical cytoplasm of the epithelial cells was thrown into by a continuous striated border of microvilli (Fig. 1C), and the basally located oval nucleus was either dark or a light color.

The apices of secreting cells of the ureter in Japanese quail possessed numerous vacuoles filled with mucus (Fig. 1D).

All epithelial cells reacted positively to neutral mucopolysaccharides with Periodic acid Schiff (PAS)-stained tissues (Figs. 1A \& B). Also, these secretory epithelial cells possessed the apical vacuoles (Fig. 1D) contained large amounts of acidic mucopolysaccharides which were detected by AB stain (Figs. 2A \& D).

Tunica mucosa formed some simple longitudinal folds which appeared to be regularly distributed over the whole luminal surface of the ureter. The mucosal folds were mostly isometric and gave the lumen a stellate appearance in crosssection (Figs. 1A \& B). The glands were observed among epithelial cells (Figs. 1B \& 2A). These mucous glands were not in some region of the ureter (Fig. 2C). The mucosal folds and microvilli were more numerous in the proximal region than those of the middle and distal regions of the ureter (Fig. $1 \mathrm{~B} \& \mathrm{C})$.

The lamina propria of the ureter contained loose connective tissue which consisted of elastic (Fig. 2B), collagen (Fig. 1D) and reticular fibers (Fig. 2C), but no lymphatic tissues were found. The muscularis mucosa was composed of a layer of longitudinally arranged smooth muscle fibers (Figs. 2A \& D), which however, were absent in some regions (Fig. 2C).

The tunica submucosa of the ureter in both sexes was formed by connective tissue containing nerve bundles, parasympathetic ganglia, blood vessels, elastic (Fig. 2B), reticular (Fig. 2C), and collagenous fibers (Fig. 1D).

The tunica muscularis was composed of an inner longitudinal layer and an outer circular layer of smooth muscle fibers (Fig. 2D). The thickness of the tunica increased gradually from the proximal to the distal region of the ureter.

The outermost tunic of the ureter was loose connective tissue which invested by mesothelium (Fig. 1A). The loose connective tissue was made up of collagen (Fig. 1D), elastic (Fig. 2B), reticular fibers (Fig. 2C), blood vessels, nerve bundles and parasympathetic ganglia (Fig. 1A). 


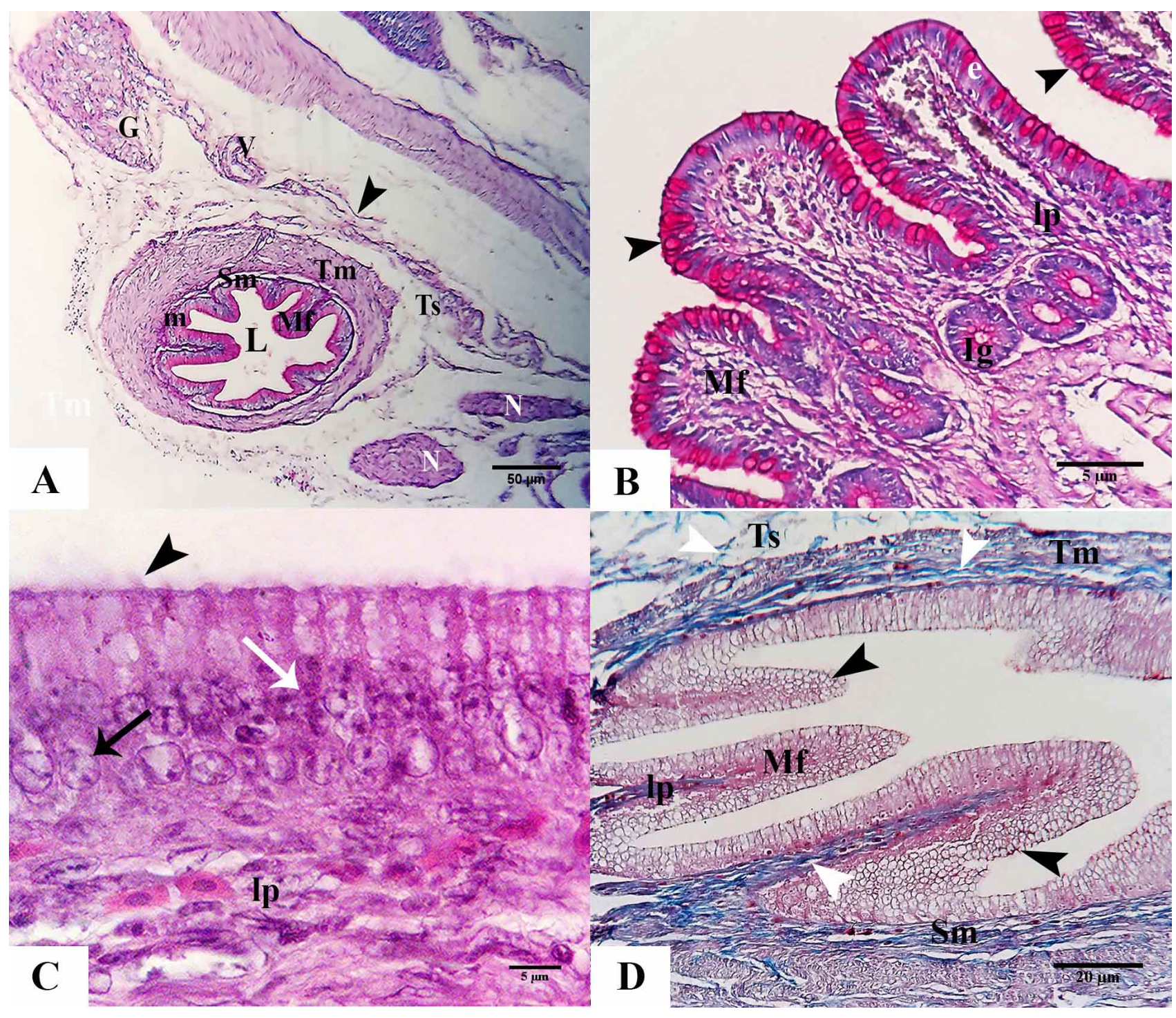

Fig. 1. The ureter of adult Japanese quail. (A) The wall of the ureter was composed of tunica mucosa (m), submucosa (Sm), muscularis $(\mathrm{Tm})$ and serosa (Ts). Note presence of isometric mucosal folds (Mf) and stellate lumen (L), blood vessels (V), nerve bundles (N), parasympathetic ganglia $(\mathrm{G})$ and connective tissue fibers (arrowhead), PAS. (B) Mucosa of the proximal ureter consists of simple columnar epithelium (e) and lamina propria (lp) that contains the glands (Ig). Note presence of strong positive reaction to PAS (arrowheads). (C) Pseudostratified columnar epithelium of the middle and distal parts of the ureter showing a dark (white arrow) or a light (black arrow) oval nucleus situated basally. Notice the presence of a continuous striated border of microvilli (arrowhead) projecting into the lumen, $\mathrm{H}$ \& E. (D) Cross section of the ureter stained by Masson's trichrome showing an abundant amount of collagenous fibers (white arrowheads) in the lamina propria (lp), submucosa ( $\mathrm{Sm})$ and serosa (Ts). Notice presence of apical vacuoles (black arrowheads) in secretory cells.

\section{DISCUSSION}

In the present study, the histology and histochemistry of the ureter showed no significant differences according to sex. This is in agreement with the results reported by Williams and Nicholson (1983) \& Abdul-Gahaffor et al. In this study, the characteristic cross sectional appearance of the ureter was that of an oval tube with a stellate lumen as reported by Williams \& Nicholson in the European starling and Abdul-Gahaffor et al. in the pigeon.

The ureter in the Japanese quail was composed of tunica mucosa, submucosa, muscularis and serosa as reported for the European starling (Williams \& Nicholson) and pigeon 


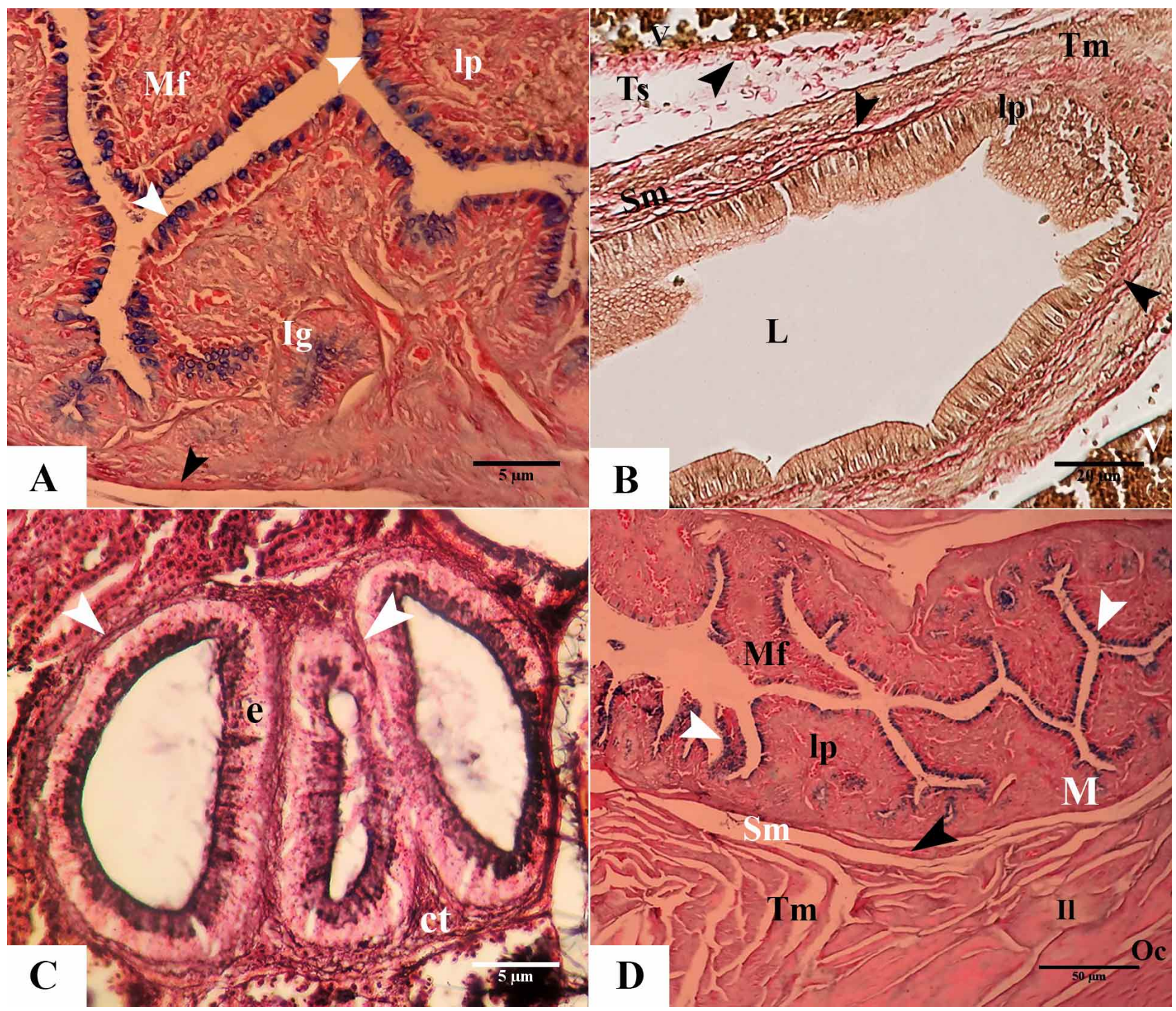

Fig. 2. Structure of the wall of the ureter of adult Japanese quail. (A) The epithelial cells show positive reaction to Alcian Blue (white arrowheads). Notice the presence of lamina muscularis mucosa (black arrowhead) and intraepithelial glands (Ig) in lamina propria (lp). (B) Cross section of the ureter stained by Verhoeff's showing abundant amount of elastic fibers (black arrowheads) in lamina propria (lp), submucosa (Sm), tunica muscularis (Tm) and serosa (Ts). (C) The smaller branches of the ureter stained by Gomori's showing epithelium (e) surrounded by connective tissue (ct). Note presence of reticular fibers (white arrowheads). (D) Cross section of the ureter stained by Alcian Blue showing tunica mucosa $(\mathrm{M})$ was separated from the submucosa $(\mathrm{Sm})$ by a conspicuous lamina muscularis (black arrowhead) and tunica muscularis (Tm) was composed of an inner longitudinal layer (Il) and an outer circular layer (Oc) of smooth muscle fibers. Note presence acidic mucosubstances in the apical part of all epithelial cells (white arrowheads).

(Abdul-Gahaffor et al.). Although some variation was found in the epithelium of the tunica mucosa, this structure was mainly lined by pseudostratified columnar epithelium as reported in previous studies (Williams \& Nicholson; Islam et al., 2001; Abdul-Gahaffor et al.).

The secondary and tertiary branches of the ureter comprised only epithelium and connective tissue fibers. This is being reported for the first time.
Williams \& Nicholson reported that in the European starling the epithelial cells were tall and two distinct rows of euchromatic nuclei appeared to be present towards the base of the epithelium, whereas Abdul-Gahaffor et al., reported that the oval nucleus occupied variable levels in the cytoplasm. The observations made in this study reveal that the ureteral epithelial cells of Japanese quail exhibited a dark or a light oval nucleus located in the basal cytoplasm. In this study, the apical cytoplasm of epithelial cells was 
covered by a continuous striated border of microvilli which is in accord with the findings of Abdul-Gahaffor et al., in the pigeon.

The mucosal histochemical reactions of the Japanese quail ureter were similar to those in previous studies (Williams \& Nicholson; Abdul-Gahaffor et al.).

The apices of secreting cells of the ureter in Japanese quail possessed numerous vacuoles filled with mucus. This finding mirrors the results of Williams \& Nicholson in European starlings, Bacha \& Bacha in chickens, and AbdulGahaffor et al., in pigeons. McNabb et al.(1973) reported that the mucus may play significant roles for binding agents for precipitated uric acid and physiological lubrication.

Abdul-Gahaffor et al. reported the presence of glands among epithelial cells of the ureter in the pigeon. These acinar glands were not found in other avian species, such as fowl (Siller, 1981), and duck (Mirabella et al.). The glands were also observed in this study.

In the present study, the number of microvilli and mucosal folds decreased gradually from the proximal to the distal ureter, which again, is in accord with the findings of Abdul-Gahaffor et al. in the pigeon.

The lamina propria of the ureter consisted of loose connective tissue which is similar to previous findings (Hodges, 1974; King \& McLelland, 1984; Aughey \& Frye; Islam et al.; Mirabella et al.; Abdul-Gahaffor et al.). This layer was made up of elastic, collagen and reticular fibers; the latter were not described in the other avian species (McNabb et al.; Siller; Williams \& Nicholson; King \& McLelland; Aughey \& Frye; Islam et al.; Mirabella et al.; Abdul-Gahaffor et al.).

In this study, the lamina muscularis mucosa was composed of a layer of longitudinally arranged smooth muscle fibers (McNabb et al.; Williams \& Nicholson; King \& McLelland; Aughey \& Frye; Mirabella et al.; AbdulGahaffor et al.). This is being reported for the first time.

The tunica submucosa of the ureter in Japanese quail was highly cellular and consisted of all the connective tissue fibers, blood vessels, parasympathetic ganglia and nerve bundles. Williams \& Nicholson reported only collagen fibers in the submucosa of the ureter in the European starling.

Abdul-Gahaffor et al. reported that the tunica muscularis of the ureter in the pigeon consisted of an inner longitudinal and an outer circular layer of smooth muscle fibers, and that the thickness of this layer of tissue increased gradually from the proximal to the distal region of the ureter. Our observations were in agreement with their results. However, Williams \& Nicholson revealed an inner circular and an outer longitudinal arrangement of smooth muscle fibers in the ureter of European starlings. Furthermore, Hodges reported the presence of a third outer longitudinal muscle coat in the ureter of the fowl which developed towards the distal end of the organ.

The tunica serosa of the ureter in the Japanese quail was loose connective tissue invested by mesothelium and consisted of connective tissue fibers, blood vessels, parasympathetic ganglia and nerve bundles. Williams \& Nicholson reported collagen fibers, blood capillaries and densely-packed fibroblasts in the European starling, and Abdul-Gahaffor et al., reported only loose connective tissue in the tunica serosa of the ureter in the pigeon.

In conclusion, the present study is the first report regarding the histological and histochemical structures of the ureter in the Japanese quail. The histological and histochemical properties of the ureter in Japanese quail were generally similar to those of the domestic pigeon and European starling except for the presence of connective tissue fibers in the lamina propria and tunica submucosa, isometric longitudinal folds in lumen and scattered muscularis mucosae in the ureter. Epithelial type, frequency of microvilli, number of mucosal folds, intraepithelial gland frequency and thickness of the tunica muscularis differed among the various regions studied.

OLIAII, A. \& MOBINI, B. las diferencias histológicas del uréter en codornices japonesas (Coturnix japonica) en comparación con algunas otras especies avícolas domésticas. Int. J. Morphol., 35(1):193-198, 2017.

RESUMEN: El objetivo de este trabajo fue determinar las diferencias histológicas de las regiones anatómicas del uréter en codornices japonesas en comparación con otras especies avícolas domésticas como la paloma, el estornino y la gallina europeos. Se obtuvieron muestras de tejido de las regiones proximal, media y distal de cada uréter y se tiñeron con $\mathrm{H} \& \mathrm{E}$, azul de Alcian ( $\mathrm{pH}$ 2,5), ácido periódico Schiff, tricrómico de Masson, método de Verhoeff y Gomori para retículo. La histología y la histoquímica del uréter mostraron diferencias considerables entre varias regiones anatómicas. No se encontraron diferencias significativas basadas en el sexo. Las ramas primarias del uréter estaban compuestas de túnica mucosa, submucosa, muscular y serosa, mientras que la pared de las ramas más pequeñas del uréter estaba constituida únicamente por epitelio y fibras de tejido conectivo. Las glándulas intraepiteliales no se encontraron en ninguna región del uréter. Los pliegues de la mucosa y las microvellosidades fueron más identificadas en la región proximal del uréter. El epitelio columnar simple de la región proximal se presentó como columnar pseudostratificado 
en otras regiones del uréter. En todas las diferentes regiones del uréter, los tejidos linfáticos no se observaron en la lámina propia. El espesor de la túnica muscular se incrementó desde la región proximal a la distal del uréter. Hallazgos inusuales del uréter en codornices japonesas lo constituyeron la presencia de fibras reticulares, elásticas y colágenas en todos los tejidos conectivos del órgano, pliegues longitudinales isométricos y mucosa muscular.

PALABRAS CLAVE: Histología; Codornices japonesas; Región; Sexo; Uréter.

\section{REFERENCES}

Abdul-Gahaffor, R.; Al-Ajeely, A. \& Mohammed, F. S. Morphohistological study on the development of kidney and ureter in hatching and adulthood racing pigeon (Columba livia domestica). Int. J. Sci. Nat., 3(3):665-77, 2012.

Aughey, E. \& Frye, F. L. Comparative Veterinary Histology with Clinical Correlates. London, Manson Publishing, 2001. pp.143-8.

Bacha, W. J. \& Bacha, L. M. Color Atlas of Veterinary Histology. $3^{\text {rd }}$ ed. Philadelphia, Wiley Blackwell, 2012. pp.184-5.

Dhyaa, A. A.; Ali, F. R.; Azhar, S. K. \& Myson, A. A. Comparative anatomical and histological features of the kidney in harrier (Circus aueroginosus), chicken (Gallus domesticus) and mallard duck (Anas platyrhynchos). Iraqi J. Vet. Sci., 38(1):107-13, 2014.

Echols, M. S. Evaluating and Treating the Kidneys. In: Harrison, G. J. \& Lightfoot, T. L. (Eds.). Clinical Avian Medicine. Vol. 2, Palm Beach, Spix Publishing, 2006. pp.451-91.

Goldstein, D. L. \& Skadhauge, E. Renal and Extrarenal Regulation of Body Fluid Composition. In: Whittow, G. C. (Eds.). Sturkie's Avian Physiology. San Diego, Academic Press, 2000. pp.265-97.

Hodges, R. D. The Histology of the Fowl. London, Academic Press, 1974. pp.488-523.

Islam, K. N.; Khan, M. Z. I.; Islam, M. N.; Ahad, A. \& Mazumder, M. S. Light microscopic structure of the ureters of Rhode Island Red (RIR) and White Leghorn Chicken (WLH) during their postnatal stages of growth and development. J. Biol. Sci., 1(4):272-4, 2001.

Kiernan, J. A. Histological and Histochemical Methods: Theory and Practice. $5^{\text {th }}$ ed. Bloxham, Scion, 2015. pp.502.

King, A. S. \& McLelland, J. Birds. Their Structure and Function. $2^{\text {nd }}$ ed. London, Baillière Tindall, 1984. pp.175-84.

Lierz, M. Avian renal disease: pathogenesis, diagnosis, and therapy. Vet. Clin. North Am. Exot. Anim. Pract., 6(1):29-55, 2003.

Luna, L. G. Manual of Histological Staining Methods of the Armed Forces Institute of Pathology. $3^{\text {th }}$ ed. New York, McGraw-Hill, 1968. pp.87164.

Mcnabb, F. M. A.; Mcnabb, R. A. \& Steeves, H. R. Renal mucoid materials in pigeons fed high and low protein diets. Auk, 90:14-8, 1973.

Mirabella, N.; Esposito, V.; Corona, M. \& Pelagalli, G. V. The morphology of the ureter in the duck (Anas platyrhynchos). Anat. Histol. Embryol., 27(4):237-43, 1998.

Mobini, B. Microscopic anatomy of the gallbladder of the Japanese quail (Coturnix coturnix japonicum). J. Vet. Adv., 4(4):488-92, 2014.

Mobini, B. \& Abdollahi, M. Effect of sex on histological and histochemical structures of different parts of the kidney in Japanese quail. Poult. Sci., 95(9):2145-50, 2016.

Nabipour, A.; Alishahi, E. \& Asadian, M. Some histological and physiological features of avian kidney. J. Appl. Anim. Res., 36:195-8, 2009.

Siller, W. G. Renal pathology of the fowl--a review. Avian Pathol., 10(3):187-262, 1981.
Williams, G. R. \& Nicholson, J. K. The histology and fine structure of the ureter of the European starling (Sturnus vulgaris). J. Anat., 136(Pt. 3):585-94, 1983.

\section{Corresponding author: \\ Dr. Behzad Mobini}

Associate Professor of Anatomical Sciences

College of Veterinary Medicine

Shahrekord Branch

Islamic Azad University

Shahrekord

IRAN

Tel. +98912 450-9704

Fax: +98 38-33361045

E-mail: dr.mobini@iaushk.ac.ir

Received:20-07-2016

Accepted:09-12-2016 